\title{
Assessment of Various Nutritional Media, Temperature and Color on Growth Behavior of Blue Oyster Mushroom in Odisha, India
}

\author{
Anamita Sen ${ }^{1}$, Arabinda Dhal ${ }^{1 *}$, Niranjan Chinara ${ }^{1}$ and Preetilagna Dhal ${ }^{2}$ \\ ${ }^{1}$ Department of Plant Pathology, ${ }^{2}$ Department of Vegetable Science, College of Agriculture, \\ OUAT, Bhubaneswar, India \\ *Corresponding author
}

A B S T R A C T

\begin{tabular}{|l|}
\hline Key w o r d s \\
Hypsizygus \\
ulmarius, Medium, \\
Temperature, \\
Colour, Growth \\
\hline Article Info \\
$\begin{array}{l}\text { Accepted: } \\
\text { 05 February } 2020 \\
\text { Available Online: } \\
\text { 10 March } 2020\end{array}$ \\
\hline
\end{tabular}

Oyster mushroom constitute thirty per cent of total mushroom production and ranks third among the cultivated mushrooms grown widely in temperate, sub-tropical and tropical regions of the World. The present investigation was undertaken to evaluate the effect of nutritional medium medium, temperature and colour on mycelial growth behaviour of Hypsizygus ulmarius in vitro. The mycelium was dense and white in potato dextrose agar (PDA) medium and required least days for full growth (10.50 days) followed by Malt Extract Medium (11.25 days). Plates incubated in $25^{\circ} \mathrm{C}$ required minimum time (10.25 days) to obtain full mycelial growth followed by $30^{\circ} \mathrm{C}$ temperature (11.25 days). Out of different colour polythene wrapping, black colour polythene treatment gave the best result as it required the least days for spawn run (16 days) followed by blue colour (16.25 days) which provided uniform growth of the medium.

\section{Introduction}

Mushrooms are fleshy, macroscopic fruiting bodies or sporocarps produced by fungi belonging to class: Basidiomycetes and Ascomycetes. These comprise a large, heterogeneous group having various shapes, size, color, appearance and edibility. Mushrooms are cosmopolitan in nature and appear in a wide variety of habitats, ranging from the Arctic regions to the Tropical regions. Total numbers of edible and medicinal mushrooms are about 10 to 14 thousands species that cover all types of mushrooms worldwide. About 2000 of these are identified as edible and about 20-60 species are commercially cultivated (Maria Florence and Balasundaran, 2000; Dündar, Yildiz, 2009) and most of these are collected as wild species. 
The Pleurotus spp. constitute thirty per cent of total mushroom production and ranks third among the cultivated mushrooms grown widely in temperate, sub-tropical and tropical regions of the world. Oyster mushroom can be easily cultivated with minimal investment and requirements. Hypsizygus ulmarius is an edible mushroom, also known as elm oyster mushroom or blue oyster mushroom. Hypsizygus ulmarius (Bull.Fr) Red Head is a Basidiomycetous fungus and belongs to family Tricholomataceae of order Agaricales. Tom Volk's (2003) reported that H. ulmarius was first named as Pleurotus ulmarius and later as put under genus Hypsizygus. H.ulmarius is a high yielding mushroom and is gaining popularity in Asia and Europe owing to its simple and low cost production technology and higher biological efficiency (Mane et al., 2007). For natural growing it is suitable in any region in India having a temperature range between $25-30^{\circ} \mathrm{C}$; whereas under controlled environment it can be grown in all the regions.

Culture medium can also play an important role for in vitro mycelial colony proliferation of mushroom (Maniruzzaman, 2004). In vitro factor i.e. temperature, colour and media are known to have direct effect on the mycelial growth. In view of this, the experiment was conducted to identify best culture medium, colour and optimum temperature for mycelial growth of Hypsizygus ulmarius in Odisha condition.

\section{Materials and Methods}

The experiments were conducted in department of plant pathology, College of Agriculture, Odisha University Of Agriculture and Technology, Bhubaneswar, Odisha. Cleaning, washing and sterilization of glasswares as well as prepared media were made aseptically. Young sporophore of Hypsizygus ulmarius was procured from the
Centre of Tropical Mushroom Research and Training (CTMRT), Odisha University of Agriculture and Technology, Bhubaneswar.

Fresh, not fully matured fruiting body was cut into small pieces from the junction of stipe and pileus. These small pieces were transferred with flame sterilized inoculation needle into petriplates containing $20 \mathrm{ml}$ solidified PDA and also into glass bottles containing $50 \mathrm{ml}$ solidified PDA to get pure culture of the fungus.

Five different media such as potato dextrose agar, malt extract agar medium, paddy straw extract agar medium, oat meal agar medium, rose bengal agar medium and potato sucrose agar medium were used to find out suitable medium for radial growth and to study the colony characters of Hypsizygus ulmarius. These inoculated petriplates were incubated at $25 \pm 2^{\circ} \mathrm{C}$ and diameter of fungal colony was observed as well as recorded after 5, 710 and 12 days of inoculation. Four replications were taken for each treatment.

Different temperatures such as 15, 20, 25, 30, $35^{\circ} \mathrm{C}$ were taken to observe mycelial growth. Twenty $\mathrm{ml}$ of PDA medium was poured on each petriplate and after solidifying the medium, inoculation of mycelia of Hypsizygus ulmarius was done from 15 days old pure culture. After inoculation, the plates were incubated under above mentioned temperatures. Four replications were taken for each treatment. Observations on radial growth of fungus were recorded in different temperatures at 5, 7, 10 and 12 days interval after inoculation.

In vitro, five colours such as black, red, blue, yellow and green were used for studying the effect of colours on mycelial growth of Hypsizygus ulmarius. Glasspapers $(0.1 \mathrm{~mm}$ thickness) of different colours were used to cover the spawn bottles. After inoculation of 
mycelia of Hypsizygus ulmarius in processed and sterilized grains (In glass bottles), different coloured glasspapers were used to wrap the bottles and incubated in $25 \pm 2^{\circ} \mathrm{C}$. Four replications were taken for each treatment. Observations on mycelial growth as well as time taken for spawn run were recorded.

\section{Results and Discussion}

In Odisha, cultivation of blue oyster mushroom has been started few years ago which performs better than other commonly grown Pleurotus spp and hence a detailed study felt to be assessed to investigate in vitro effect of different media, temperature and colour on mycelial growth of Hypsizygus ulmarius.

In this experiment, six different media were taken to study the growth and evaluate the efficacy and suitability of media for Hypsizygus ulmarius. The performance of growth in different media are presented in table 1 .

Assessment of suitability of various media revealed that maximum mycelial growth after 10 days of inoculation was observed in PDA medium $(8.97 \mathrm{~cm})$ which was statistically at par with malt extract $(8.91 \mathrm{~cm})$, paddy straw extract $(8.72 \mathrm{~cm})$ and Rose Bengal Agar medium $(8.21 \mathrm{~cm})$ whereas least growth was observed in Oat meal agar medium $(6.59 \mathrm{~cm})$. Similarly, the least days required for full mycelial growth was in PDA medium (10.50 days) which was statistically at par with malt extract medium (11.25 days). White and dense mycelium was found in both PDA and oat meal agar medium where as pale white but quick growth with regular margin /periphery was observed in case of malt extract medium. The effectiveness of PDA and Malt Extract Agar was also demonstrated by Jatav et al., (2012), Mishra et al., (2015), Sutha and Eswarna (2016). PDA medium was the best for growth of Hypsizygus ulmarius (9 $\mathrm{cm}$. in 8.75 days) followed by Malt Extract Agar (8.75 cm in 9.25 days) which is in close conformity with the present findings (Sumi and Geetha, 2016). To investigate the optimum temperature required for mycelial growth, an experiment was conducted where the fugus Hypsizygus ulmarius was inoculated in petriplates containining PDA media. Then after the plates were incubated in different temperatures such as $15,20,25,30$ and $35^{\circ} \mathrm{C}$ temperature and the results are presented in table 2.

Table.1 Effect of different media on mycelial growth of Hypsizygus ulmarius

\begin{tabular}{|l|c|c|c|l|}
\hline SI No. & $\begin{array}{c}\text { Treatments } \\
\text { (media) }\end{array}$ & $\begin{array}{c}\text { Growth after 10 } \\
\text { days of } \\
\text { inoculation } \mathbf{( c m )}\end{array}$ & $\begin{array}{c}\text { Days } \\
\text { required for } \\
\text { full growth }\end{array}$ & \multicolumn{1}{|c|}{ Growth characteristics } \\
\hline $\mathbf{1}$ & Potato Dextrose Agar & 8.97 & 10.50 & white, dense mycelium \\
\hline $\mathbf{2}$ & Malt extract Agar & 8.91 & 11.25 & Pale white, regular margins at periphery \\
\hline $\mathbf{3}$ & $\begin{array}{c}\text { Potato Dextrose Rose } \\
\text { Bengal Agar }\end{array}$ & 8.21 & 14.00 & $\begin{array}{l}\text { Cottony white mycelium, irregular } \\
\text { margins }\end{array}$ \\
\hline $\mathbf{4}$ & Oat meal Agar & 6.59 & 16.25 & Milky white, dense mycelium \\
\hline $\mathbf{5}$ & Potato Sucrose Agar & 7.74 & 14.75 & $\begin{array}{l}\text { White and loose mycelium, margins are } \\
\text { regular }\end{array}$ \\
\hline $\mathbf{6}$ & Paddy straw extract & 8.72 & 12.75 & Transparent to dull whitish mycelium \\
\hline & SE(m) & 0.31 & 0.91 & \\
\hline & C.D (0.05) & 0.92 & 1.93 & \\
\hline
\end{tabular}


Table.2 Effect of temperature on mycelial growth of Hypsizygus ulmarius in vitro

\begin{tabular}{|c|c|c|c|c|c|}
\hline $\mathbf{S L}$ & $\begin{array}{c}\text { Temperature } \\
\text { No }\end{array}$ & $\begin{array}{c}\text { Growth after } \\
\text { 5 days of } \\
\text { inoculation } \\
\text { (cm) }\end{array}$ & $\begin{array}{c}\text { Growth after } \\
\text { 8 days of } \\
\text { inoculation } \\
\text { (cm) }\end{array}$ & $\begin{array}{c}\text { Growth after } \\
\text { 10 days of } \\
\text { inoculation } \\
\text { (cm) }\end{array}$ & $\begin{array}{c}\text { Days } \\
\text { required } \\
\text { for full } \\
\text { growth }\end{array}$ \\
\hline $\mathbf{1}$ & $\mathbf{1 5}$ & 0.19 & 0.25 & 1.58 & 25 \\
\hline $\mathbf{2}$ & $\mathbf{2 0}$ & 0.55 & 0.98 & 1.75 & 18.25 \\
\hline $\mathbf{3}$ & $\mathbf{2 5}$ & 4.00 & 7.08 & 8.96 & 10.25 \\
\hline $\mathbf{4}$ & $\mathbf{3 0}$ & 3.40 & 6.96 & 8.14 & 11.25 \\
\hline $\mathbf{5}$ & $\mathbf{3 5}$ & 1.74 & 3.86 & 6.03 & 13.25 \\
\hline & $\mathbf{S E}(\mathbf{m}) \pm$ & 0.21 & 0.16 & 0.15 & 0.56 \\
\hline & C.D (P=0.05) & 0.65 & 0.49 & 0.46 & 1.71 \\
\hline
\end{tabular}

Table.3 Effect of colour polythene on mycelial growth of Hypsizygus ulmarius in vitro

\begin{tabular}{|c|c|c|c|c|}
\hline $\begin{array}{c}\text { Sl } \\
\text { NO }\end{array}$ & $\begin{array}{l}\text { Treatment } \\
\text { (coloured } \\
\text { polythene) }\end{array}$ & $\begin{array}{l}\text { Mycelial growth } \\
15 \text { days after } \\
\text { inoculation }(\mathrm{cm})\end{array}$ & $\begin{array}{l}\text { Time taken for } \\
\text { full mycelial } \\
\text { growth (days) }\end{array}$ & Growth Characteristics \\
\hline 1 & Black & 10.09 & 16.00 & Mycelia is dense, cottony white \\
\hline 2 & Blue & 9.97 & 16.25 & Uniform growth of mycelium \\
\hline 3 & Green & 9.92 & 17.25 & $\begin{array}{l}\text { Mycelial growth towards bottom } \\
\text { of bottle is comparatively uniform }\end{array}$ \\
\hline 4 & Red & 9.96 & 17.00 & $\begin{array}{l}\text { Mycelia uniformly distributed } \\
\text { throughout the grains. }\end{array}$ \\
\hline 5 & Yellow & 9.63 & 18.00 & $\begin{array}{l}\text { Mycelial growth is not uniform in } \\
\text { all grains }\end{array}$ \\
\hline 6 & $\begin{array}{c}\text { Control } \\
\text { (Transparent) }\end{array}$ & 9.75 & 17.50 & $\begin{array}{l}\text { All grains are not uniformly } \\
\text { covered by mycelial growth, poor } \\
\text { growth in bottom of bottle }\end{array}$ \\
\hline & $\mathrm{SE}(\mathrm{m}) \pm$ & 0.06 & 0.34 & \\
\hline & C.D $(P=0.05)$ & 0.17 & 1.03 & \\
\hline
\end{tabular}

A temperature of $25^{\circ} \mathrm{C}$ was found optimum for mycelial growth of Hypsizygus ulmarius as maximum growth after 10 days of inoculation was observed in those petriplates incubated in $25^{\circ} \mathrm{C}$ temperature $(8.96 \mathrm{~cm})$ followed by $30^{\circ} \mathrm{C}$ temperature $(8.14 \mathrm{~cm})$ and also minimum time required for full growth of Hypsizygus ulmarius was recorded in $25^{\circ} \mathrm{C}$ temperature (10.25 days) which was statistically at par with $30^{\circ} \mathrm{C}$ temperature
(11.25 days). However, maximum days required for full mycelial growth was observed in $15^{\circ} \mathrm{C}$ temperature and hence not suitable for growth of the fungus Hypsizygus ulmarius. These findings corroborated the findings of Saxena and Rai (1994), Rout et al., (2015), Sutha and Eswarna (2016) and Sharma et al., (2018).

Spawn bottles were wrapped with $0.1 \mathrm{~mm}$ 
thick colored polythene and to compare growth pattern as well as spawn run days, five different types of colored polythene were used viz: black, blue, green red and yellow. Bottles without wrapping with any color polythene were considered as control and findings depicted in table 3.

Results emphasized that mycelial growth after 15 days of inoculation is more in case of black polythene wrapped bottle, $(10.09 \mathrm{~cm})$ which was statistically at par with blue $(9.97 \mathrm{~cm})$, red $(9.96 \mathrm{~cm})$ and green colour polythene treatment $(9.92 \mathrm{~cm})$. It was also noticed that black colour polythene treatment gave the best result as it required the least days for spawn run (16 days) which were at par with blue (16.25 days) and red colour treatment(17 days). Considering the growth behaviour, the black, blue and red colour were found much effective as they produced dense, cottony white growth of Hypsizygus with uniform and compact growth of mycelium in the spawn bottles. Chandravanshi (2007) in one similar experiment found the radial growth of Hypsizygus ulmarius was significantly more $(76.66 \mathrm{~mm})$ in plates wrapped with black gelatin sheet which supports the present findings. Furlan et al., (1997) also reported that dark condition favoured the mycelial growth in Pleurotus ostreatus which is also in close agreement with the present findings.

It can be concluded that PDA is the best medium for mycelial growth of Hypsizygus ulmarius. Optimum temperature required for growth of this mushroom species is $25^{\circ} \mathrm{C}$ and black coloured polythene wrapping gave the best result as it required the least days for spawn run .

\section{References}

Chandravanshi, P. 2007. Studies on blue oyster mushroom (Hypsizygus ulmarius,
Bull. ex. Fr.) Chhattisgarh. M.Sc.(Ag) thesis. Indira Gandhi Agricultural University, Raipur, Chhattisgarh.

Dündar A., Yildiz A., 2008. A comparative study on Pleurotus Ostreatus (Jacq.) P. Kumm. cultivated on different agricultural lignocellulosic wastes, Turk J Biol, 33(2); 171-179 .

Furlan SA, Virmond LJ, Miers DA, Bonatti M, Gem R.M.M. and Jones R. 1997. Mushroom strains able to grow at high temperature and low $\mathrm{pH}$ values. World Journal of Microbiology and Biotechnology, 13:689-692.

Jatav RS Gupta AK, Anila D and Meena AK. 2012. Studies on different physical factors on mycelia growth of blue oyster mushroom (Hypsizygus ulmarius (Bull.) Redhead). Int. J. Agric. Statist. Sci. 8(1):347-354.

Mane VP, Patil SS, Syed AA and Baig MMV.2007. Bioconversion of low quality lignocellulosic agricultural wastes into edible protein by Pleurotus sajorcaju (Fr.) Singer. J. Zhejiang Univ. of Sci.B, 8 (10):745-751.

Maniruzzaman, M. 2004. Influence of media composition and growth regulators on mycelial. growth and spawn production of three mushroom species. MSc. Thesis, Department of Biotechnology, BAU, Mymensingh.

Maria Florence E.J and Balasundaran M., 2000 Mushroom Cultivation Using Forest Litter and Waste Wood. KFRI Research Report 19:28.

Mishra RP, Mohammad S, Sonika P, Manjul P, Deepshikha and Mandvi S.2015. Characterization of Pleurotus sp. of mushroom based on phenotypic, biochemical and yield parameter, Afr. J. Microbiol. Res, 9(13): 934-937.

Rout MK, Mohapatra KB, Mohanty P and Chandan SS. 2015. Studies on effect of incubation temperature and light 
intensity on mycelia growth of oyster species. Journal of Crop and Weed. 11(2): 44-46.

Saxena S and Rai RD. 1994. Environmental aspects of crop management in mushrooms, Advances in Mushroom Biotechnology, 98; 40-51.

Sharma PK, Singh F, Singh S and Dhawan A. 2018. Effect of Physiological Parameters on Mycelial Growth of Blue Oyster [Hypsizygus ulmarius (Bull.:Fr.) Redhead] Mushroom, International Journal of Current Microbiology and Applied Sciences, 7(6); 2440-2445.

Sumi I and Geetha D.2016. Physiological and cultural studies on blue oyster mushroom, Hypsizygus ulmarius. Int $J$. of Applied and pure sci. and Agric.2(6): 33-38.

Sutha RKR and Eswaran A. 2016. Effect of surface sterilants on the tissue germination and biomass production of Hypsizygus ulmarius (Bull.:Fr.) Redhead (blue oyster mushroom), Asian J. Pharma. Biol. Res. 7(1): 2289-2293.

Tom Volk's. 2003. Tom Volk's Fungus of the Month of March, 2003. This month's fungus Marasmius oreades, the fairy ring mushroom. Tom Volk Fungi. Net.

\section{How to cite this article:}

Anamita Sen, Arabinda Dhal, Niranjan Chinara and Preetilagna Dhal. 2020. Assessment of Various Nutritional Media, Temperature and Color on Growth Behavior of Blue Oyster Mushroom in Odisha, India. Int.J.Curr.Microbiol.App.Sci. 9(03): 842-847.

doi: https://doi.org/10.20546/ijcmas.2020.903.099 